\title{
EXTRACTS OF POMEGRANATE, PERSIMMON, NETTLE, DILL, KALE AND SIDERITIS SPECIFICALLY MODULATE GUT MICROBIOTA AND LOCAL CYTOKINES PRODUCTION: IN VIVO STUDY
}

\author{
T. Meleshko, O. Pallah, V. Petrov, N. Boyko
}

\begin{abstract}
Метою роботи було виявлення (іп vivo, на моделі імунокомпетентних мишей) динаміки впливів перорального введених екстрактів їстівних рослин - інградієнтів традиційних харчових продуктів - на стан кишкової мікробіоти та продукування цитокінів слизовими оболонками кишечнику.

Матеріали і методи. У дослідженні було сформовано сім груп імунокомпетентних мишей $B A L B / c$, які протягом 14 днів перорально випоювались рослинними екстрактами (15 мг/200 мкл/миша). Останні одержували за розробленою нами технологією із харчових продуктів рослинного походження - капусти кале, кропу, Sideritis scardica, кропиви, плодів хурми і гранату. Матеріалом мікробіологічного аналізу змін кишкової мікробіоти слугував вміст товстої кишки. Ключових представників мікробіоти ізолювали шляхом висіву серійних розведень на селективні хромогенні поживні середовища та ідентифікували серологічно і біохімічно. Продукцію ицтокінів різними відділами китечнику та лімфатичної тканини, асоційованої із слизовими оболонками кишечнику, визначали методом імуноферментного аналізу.

Результати. В експериментах на мишах доведено здатність екстрактів капусти кале, кропу $i$ Sideritis при їх оральному застосуванні вибірково інгібувати вміст E. coli, K. pneитопіае, E. faecalis, L. acidophilus y товстій кишиі митей, стимулюючи при изьому ріст B. bifiduт. Показано, що екстракт кропиви призводить до збільшення кількості E. coli, а екстракт хурми - до зростання популяційних рівнів E. faecalis, Bifidobacterium та зменшення вмісту Candida spp. Eкстракт гранату специфічно стимулює ріст Bifidobacterium. Існують значні відмінності у продукуванні ичтокінів в супернатантах культури фрагментів тканин $і$ в сироватці крові мишей при оральному введенні різних рослинних екстрактів. Екстракт кропу зумовлює системне і локальне збільшення ФНП-а та IЛ-2, а екстракти кропиви та Sideritis викликають таке збільшення лише на ділянках слизової оболонки. Екстракти гранату, хурми та капусти кале системно і локально стимулюють продукування ІЛ-2, ІЛ-10, ІЛ-12, ІФН-ү та ІЛ-17, але не ФНП- $\alpha$.

Висновки. Найбільш виразними корисними властивостями щцодо впливу на стан кишкової мікробіоти та продукування циитокінів слизовими оболонками кишечнику володіють екстракт хурми, а також екстракти гранату та капусти кале. Екстракти кропиви та кропу демонструють протизапальну дію. Екстракт Sideritis був нейтральним до більшості досліджуваних показників. Жодний з екстрактів не виявив шкідливих впливів

Ключові слова: екстракти їстівних рослин, імуномоделююча дія, кишкова мікробіота
\end{abstract}

Copyright (C) 2020, T. Meleshko, O. Pallah, V. Petrov, N. Boyko. This is an open access article under the CC BY license (http://creativecommons.org/licenses/by/4.0).

\section{Introduction}

Human microbiome as well as how microorganisms affect the immune system is the frontier research topic. Host-microbial interaction and the possibility of targeted regulation of [gut] microbiota following to maintenance mucosal immune response is subject of great practical interest for prevention and treatment of noncommunicable diseases (NCD) initiated by low grade inflammation.

The anti-aggregate effects of the same extracts of pomegranate, persimmon, nettle, dill, kale and Sideritis as well as their antioxidant properties by affect molecules related to endothelial NO release and vasodilation $[1,2]$. However, their ability to modulate gut microbiome and local immune response was not studied (remains unclear).

\section{Literature review}

Modern human nutrition needs to meet a lot of demands and provide not only safe and necessary composition of micro and microelements, but also be functional, which means enable the prevention of the development or even treatment of various diet-associated diseases, such as type II diabetes (T2D), cardiovascular diseases (CVD), etc. [3].

The fruits, vegetables, whole grains and other traditional foods are the major source of the biologically active components (BAC). It is largely known that bioactive compounds and their correlation with antioxidant capacity are insured of quality parameters typical/proved for the commercial fruit-based baby foods [4], and mainly represented by vitamins, trace elements and antioxidants (polyphenols, anthocyanins, etc.) [5]. 
It is known that these phytochemicals are influenced on the various important processes occurring in the human body, including gene expression, production of enzymes and hormones, activation of receptors, immune and antioxidant processes, etc. [6]. It is known that BAC have long been used in practical medicine, in particular, a well-known trend of the last decades is the construction of modern preparations based on them - prebiotics and synbiotics [7].

It is well known that the gut microbiota plays a major role in host health by shaping the development of the immune system, metabolizing dietary nutrients (such as fatty acids, glucose and bile acids) and drugs, digesting complex indigestible polysaccharides and synthesizing vitamins and bioactive molecules $[8,9]$. The changes of the gut microbiota may partially contribute to the higher incidences of chronic inflammatory disorders, such as cardiovascular disease, obesity, depression, allergies, diabetes and autoimmune disorders [9].

It has been shown that the gut microbiota is critical for intestinal immune maturation [10]. Gut microbiota-stimulated immune maturation maintains gut homeostasis by protecting the host from infections [11], and damaging inflammatory responses [12].

It is therefore clear that it is essential to understand the biological interactions between the food ingredients, microbiota, and immune system.

\section{The aim and objectives of the research}

The aim of this study was to use the in vivo model to reveal main changes in gut microbiota in dynamic of immunocompetent BALB/c mice and find out the specificity of action of targeted foods/plants extracts on cytokines production in all gut compartments and GALT to its oral administration. To achieve the aim, the following tasks were set:

1. To detect changes in murine microbiota composition as major players of regulation of mucosal immune response.

2. To measure production of pro-inflammatory and anti-inflammatory cytokines in fragment culture of small intestine and gut associated lymphoid tissues (GALT), including Payer Patches (PPs), peritoneal cavity (PC), mesenteries lymph nodes (MLN), following oral administration of selected edible plants extracts.

\section{Materials and methods}

\section{Plants/extracts/foods}

In our experiment we use extracts from six edible plants obtained by our colleagues as part of the international project "BaSeFood" at the Institute of Food Research (Norwich, UK). Plants such as kale leaves (Brassica oleracea var. acephala), persimmon (Diospyros species), pomegranate (Punica granatum), dill (Anethum graveolens), Sideritis scardica, and nettle (Urtica dioica) were components of traditional food and were sourced from areas of the Black Sea region. Extraction of plant raw materials was carried out by the method of quantitative extraction by methanol according to the analytical scale. Fresh plant materials were weighed and introduced into the hot aqueous solution of methanol $\left(65-70{ }^{\circ} \mathrm{C}\right)$ at a plant material/aqueous methanol ratio of 1:10. Methanol-free ex- tracts of selected plants were obtained by vacuum evaporation.

\section{Animal groups}

In this study, seven groups of immunocompetent $\mathrm{BALB} / \mathrm{c}$ mice were formed. All experimental mice had been fed orally by plants' extracts $(15 \mathrm{mg} / 200 \mu \mathrm{l} / \mathrm{mouse})$ for the 14th days. During the experiment, all animals were orally consuming different ingredient(s), in addition to the standard food received by the control group, depending on the experimental group:

Group 1 - kale leaves extract;

Group 2 - persimmon extract;

Group 3-pomegranate extract;

Group 4 - dill extract;

Group 5 - Sideritis extract;

Group 6-nettle extract;

Group 7 - control group, standard vivarium diet food. 3 animals were used per extract per 1 time point day $3 \mathrm{rd}$, 7th, 14th, 21st, 28th and 1 month - wash out period - and were sacrificed and worked up separately. To determine local secretion of cytokines, tissue fragments $\left(3 \mathrm{~mm}^{2}\right.$ each) of the spleen, PPs, MLNs and small intestine: Duodenum (D), Jejunum (J), and Ileum (I) were cultured for 2 weeks in Kennet's HY medium in a microanaerobic chamber at a ratio of $\mathrm{CO}_{2}$ and $\mathrm{O}_{2}$ gases of $90 \%$ and $10 \%$ respectively [13].

All experiments in mice were performed in accordance with the international principles outlined by the European Convention for the Protection of Vertebrate Animals Used for Experimental and Other Scientific Purposes (Strasbourg, 1986) signed by the Verkhovna Rada of Ukraine in 2002, Law of Ukraine No. 3447 - IV "On the Protection of Animals from Cruelty", meeting minutes of the Bioethics Commission of the Medical Faculty of the State University "Uzhhorod National University” (Minutes No. 4, dated March 16, 2011).

\section{Microbiological assay}

In order to detect changes in murine microbiota composition on the $3 \mathrm{rd}, 7 \mathrm{th}, 14 \mathrm{th}, 21 \mathrm{st}, 28 \mathrm{th}$ days and 1 month from the beginning of the experiment $1 \mathrm{~g}$ of feces was collected from the experimental animals and mixed with $1 \mathrm{ml}$ of PBS. Ten-fold serial dilution of samples was performed and plated correspondingly on the growth media such as: RAPID'E.coli $2^{\mathrm{TM}}$ medium, UriSelect 4 (Bio-Rad, USA), Sabouraud Dextrose Agar, Lactobacillus MRS Agar, Bifidobacterium Agar, Bile Esculin Agar, MacConkey Agar (HiMedia Laboratories, India). Counting of all types of microorganisms was carried out according to the formula: $\mathrm{CFU} / \mathrm{g}=\mathrm{a} \times \mathrm{b} \times \mathrm{c}$, where: a stands for the number of colonies grown on the nutrient medium; b stands for dilution coefficient dose (when plating $100 \mu \mathrm{l}, \mathrm{a}=10$; when seeding $50 \mu \mathrm{l}, \mathrm{a}=5$; when plating $10 \mu \mathrm{l}, \mathrm{a}=100$ ); and $\mathrm{c}$ stands for dilution factor. For biochemical identification semi-automatic systems (API BIOMERIEUX/LACHEMA/PAST tests, OKI diagnostics) had been used.

\section{ELISA}

The production of cytokines were detected by Enzyme-linked immunosorbent assay (ELISA) using the BioLegend's ELISA MAX ${ }^{\mathrm{TM}}$ Deluxe Set Mouse IL-2, IL-10, IL-12, IL-17, TNF-a, IFN-g kitsand Immunoenzyme Analyzer BioTek Elx800 at $450 \mathrm{~nm}$. Serum and fragment culture samples were previously diluted in con- 
centration $1: 1,1: 5,1 ; 25$ and $1: 125$, and all the samples (each mouse was worked out separately, each tissue: duodenum, jejunum, ileum, PPs, MLNs were cultivated in triplicate for each time points: $3 \mathrm{rd}, 7 \mathrm{th}, 14 \mathrm{th}, 21 \mathrm{st}$ and 28th day and for the wash out period) were also measured in triplicate.

\section{$\underline{\text { Statistics }}$}

Statistical analyses were performed using the statistical program GraphPad Prism version 3.00. Tukey's and Dunnett's tests (after analysis of variance, ANOVA) were used to identify the differences between groups. In tables are presented results from Dunnett's test - meaning that all experimental groups were compared against control.

\section{Research results and discussion} $\underline{\text { in gut content }}$

Changes in mice (BALB/c) gut microbiota tested

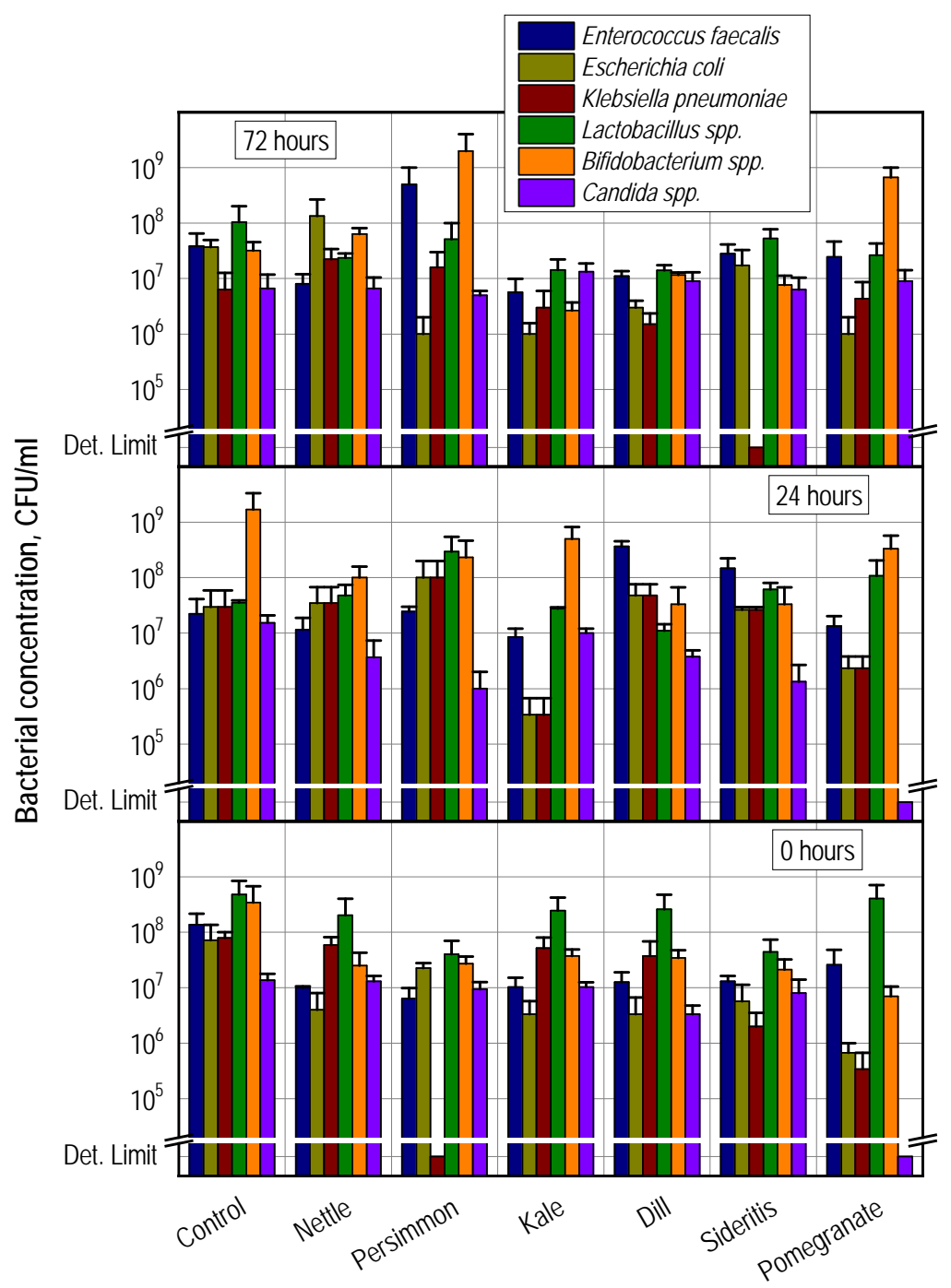

Fig. 1. The major patterns of changes detected on the first hours after selected edible plants' extracts administration to $\mathrm{Balb} / \mathrm{c}$ mice
The short-term effects of extracts on the composition of the gut microbiota were studied. Gut content was collected:

1) immediately after oral administration of selected plants' extracts ( 0 or 1 hour),

2) 24 hours, and

3) 48 or 72 hours

The Fig. 1 is presenting the overall (panoramic) results of this first preliminary acute experiment, namely the effect of each of the tested extracts in the first 4872 hours of mice feeding on the colon microbiota.

In the second performed experiment the long-term effects of the same extracts on the gut microbiota of $\mathrm{BALB} / \mathrm{c}$ mice has been studied. Persistence of gut microorganisms had been detected in colon in another experiment when mice were sacrificed on days $3 \mathrm{rd}$, 7th, 14th, 21st, and 28th wash out period (Fig. 2-8 including the control). 


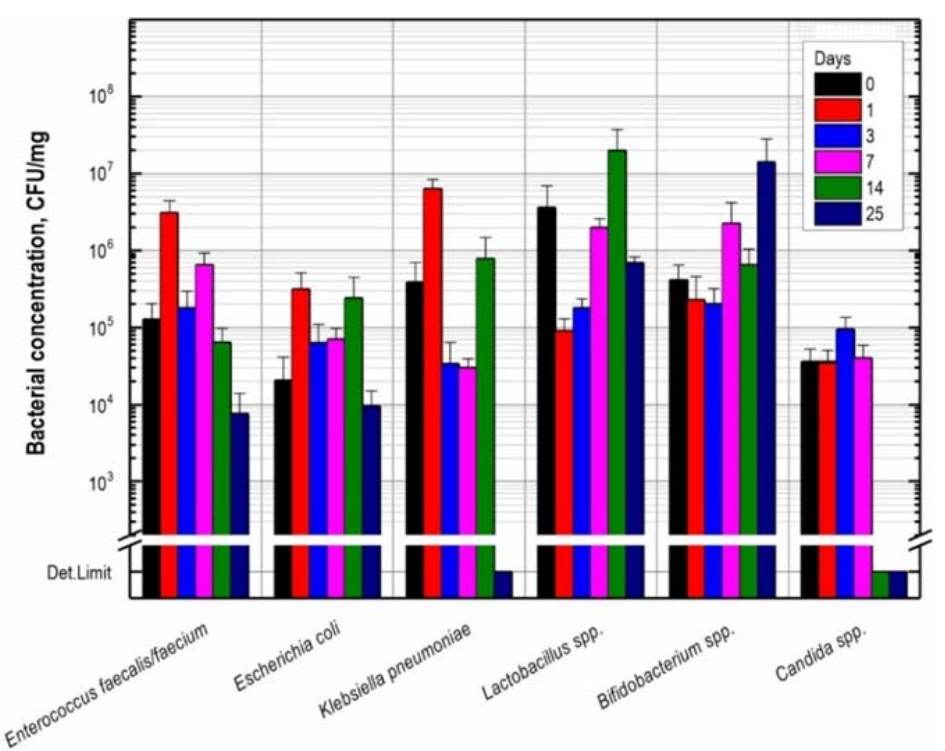

Fig. 2. Effect of oral administration of Dill extract on murine gut microbial composition

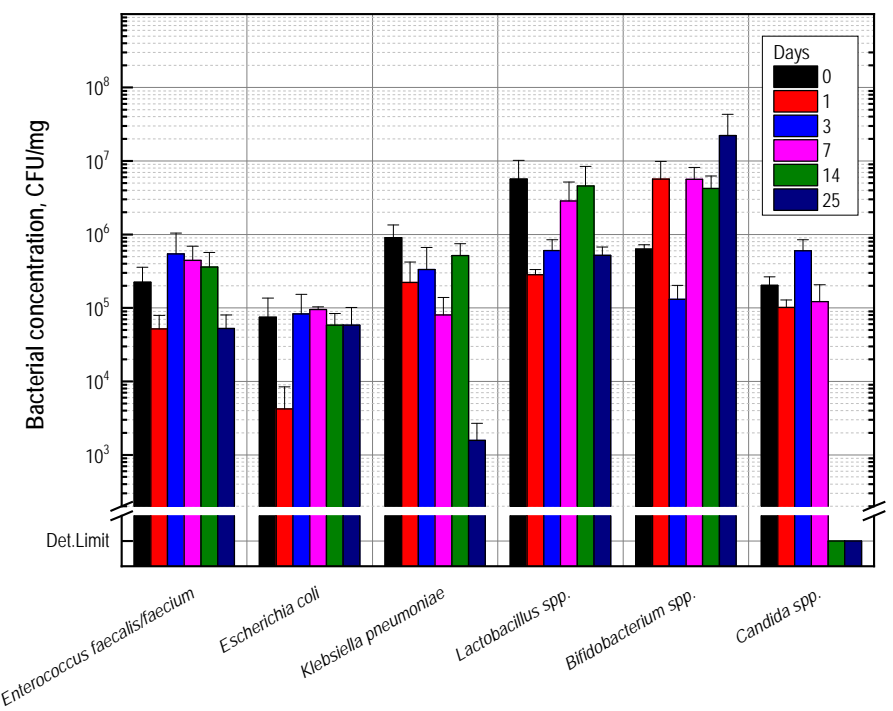

Fig. 3. Effect of oral administration of Kale extract on murine gut microbial composition

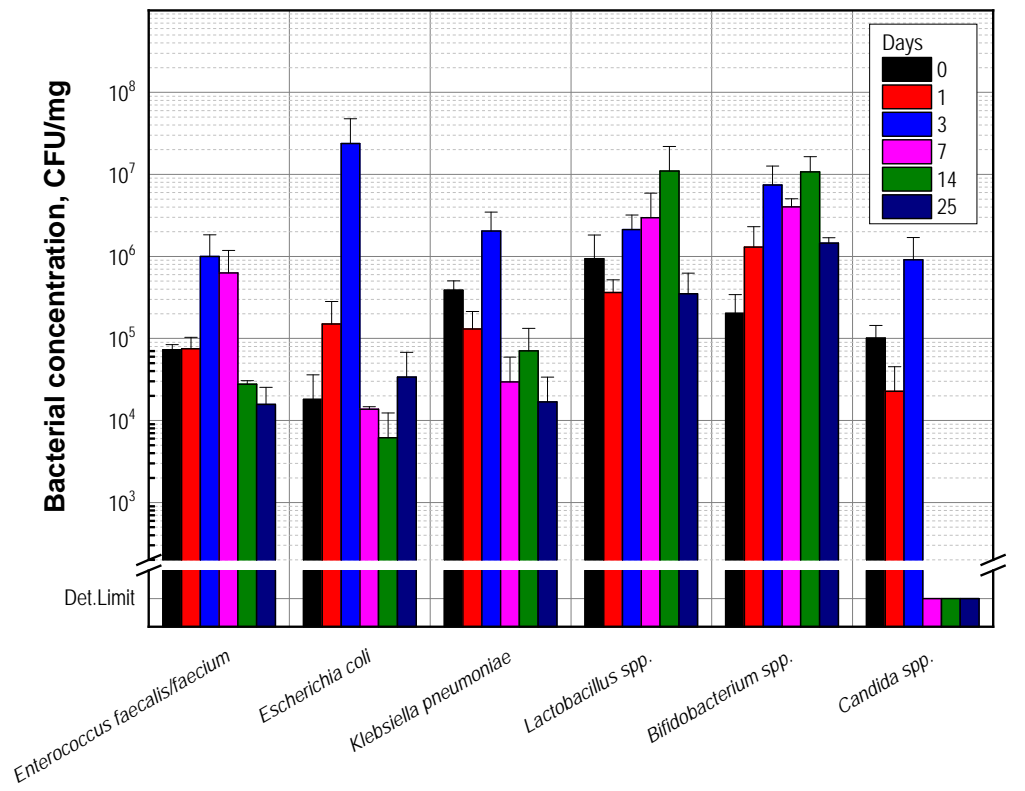

Fig. 4. Effect of oral administration of Nettle extract on murine gut microbial composition 


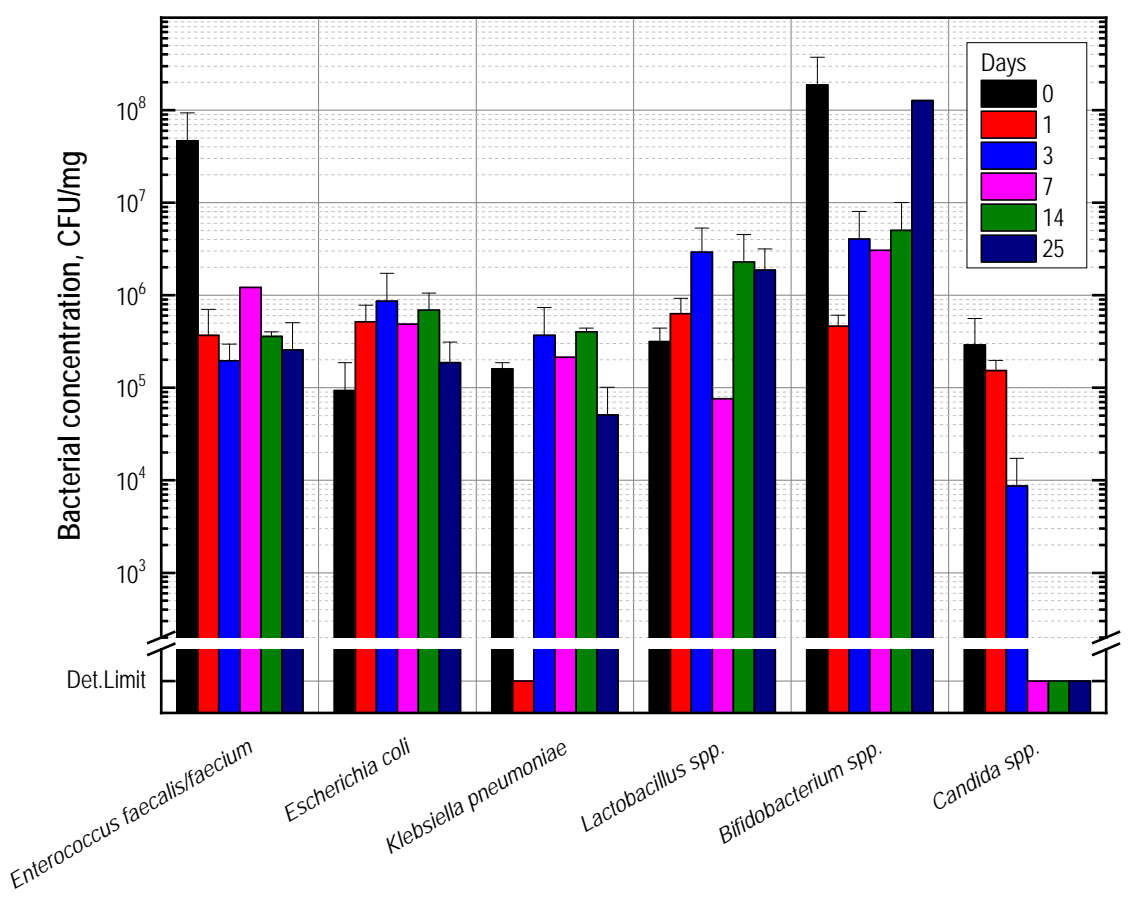

Fig. 5. Effect of oral administration of Sideritis extract on murine gut microbial composition
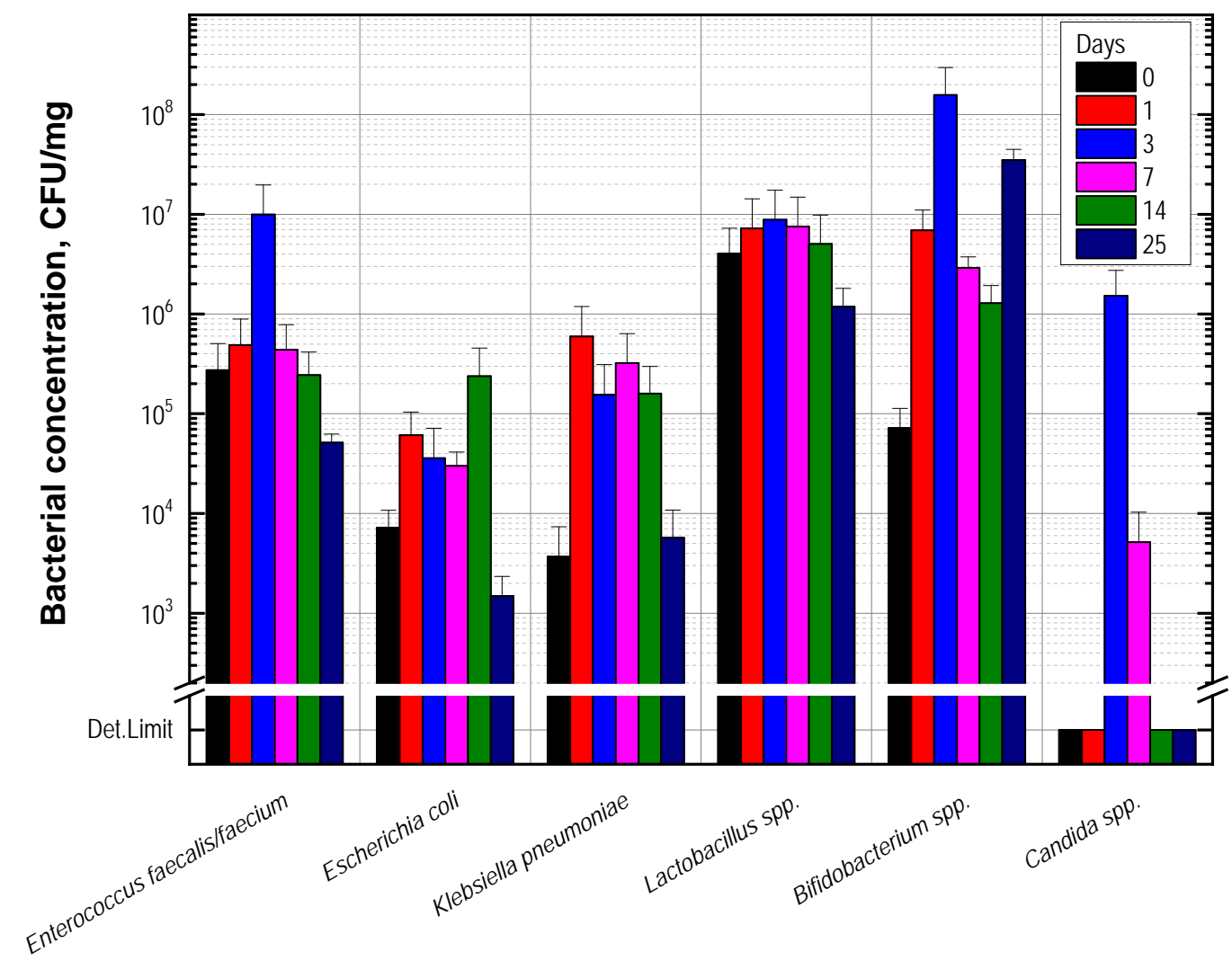

Fig. 6. Effect of oral administration of Pomegranate extract on murine gut microbial composition 


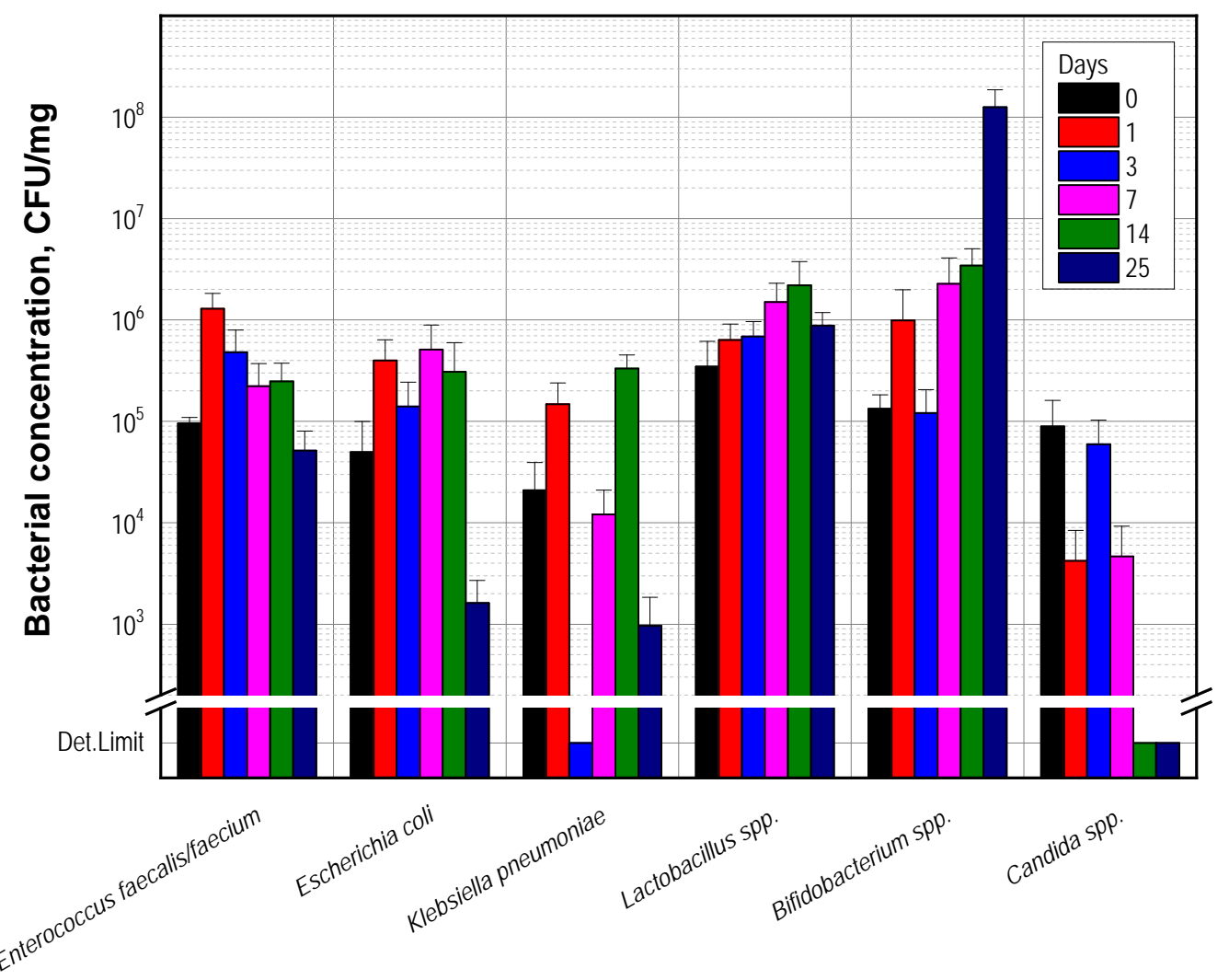

Fig. 7. Effect of oral administration of Persimmon extract on murine gut microbial composition

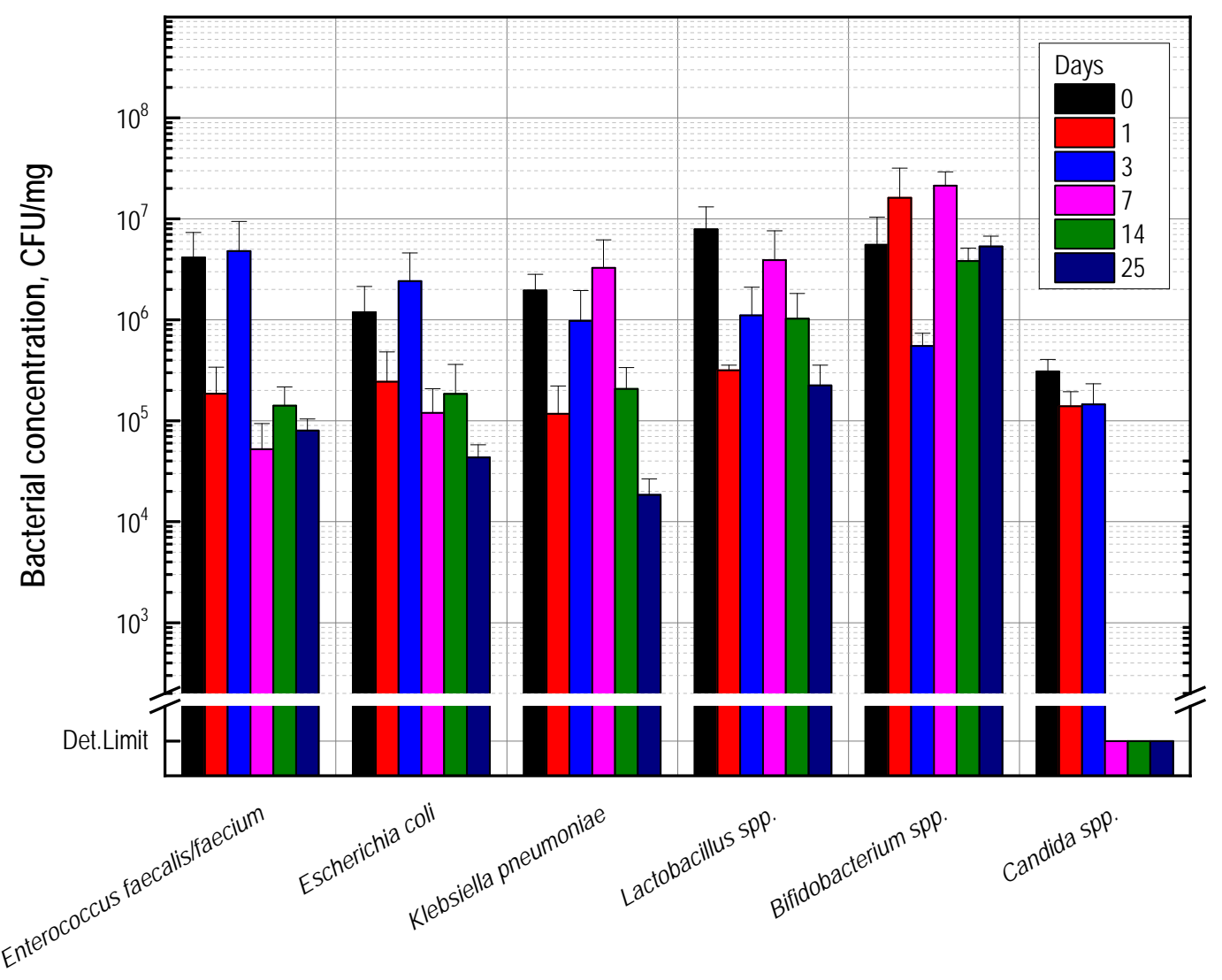

Fig. 8. Control mice: microbiota composition in murine gut 
On the mouse model it was shown that the extract of dill inhibited two Enterococcus strains (E. faecalis and E. faecium), Klebsiella pneumoniae and Lactobacillus spp., and stimulated Bifidobacterium bifidum. Bifidobacteria were also stimulated by the kale extract, but in this case there were no significant effects on any of the other tested gut microbiota.

The nettle extract caused a non-specific stimulation of gut microbial composition on day 3, whereas by days 14 and 24 all the indices were approximately equal to their initial levels (for E. coli and $K$. pneumoniae), but lactobacilli and bifidobacteria were both dramatically reduced.

Persimmon extract was the only extract able to specifically stimulate lactobacilli, while the pomegranates extract specifically stimulated bifidobacteria.

The Sideritis extract effectively inhibited $K$. pneumoniae and commensal E. coli, and also induced a statistically significant increase in bifidobacteria and a moderate but non-significant increase in lactobacilli (Fig. 9).

\section{duction}

Effect of edible plant extracts on cytokines pro-

The pro- and anti-inflammatory cytokine profiles in all specimens of isolated tissue fragments (parts of the small intestine - duodenum, jejunum and ileum, MLN, PPs) and serum of the BALB/c mice after oral administration of the plants' extracts had been determined.

The differences in the levels of cytokines produced in the culture supernatants of tissue fragments and in the serum of mice with the oral administration of various plant extracts has been detected. In Fig. 10-12, the data obtained for kale, persimmon and pomegranate extracts on days 3, 7, 14, 21 and 28 of the experiment is introduced. Consumption of dill extract has the ability to stimulate the production of only IL-2 in the range from $2.35 \mathrm{pg} / \mathrm{ml}$ in the duodenum to $2 \mathrm{pg} / \mathrm{ml}$ in serum. Similar is the effect of Sideritis extract consumption, which also stimulates to a large extent the synthesis of IL-2 locally, in the duodenum, jejunum and ileum from $2.11 \mathrm{pg} / \mathrm{ml}$ to $2 \mathrm{pg} / \mathrm{ml}$ had been shown.

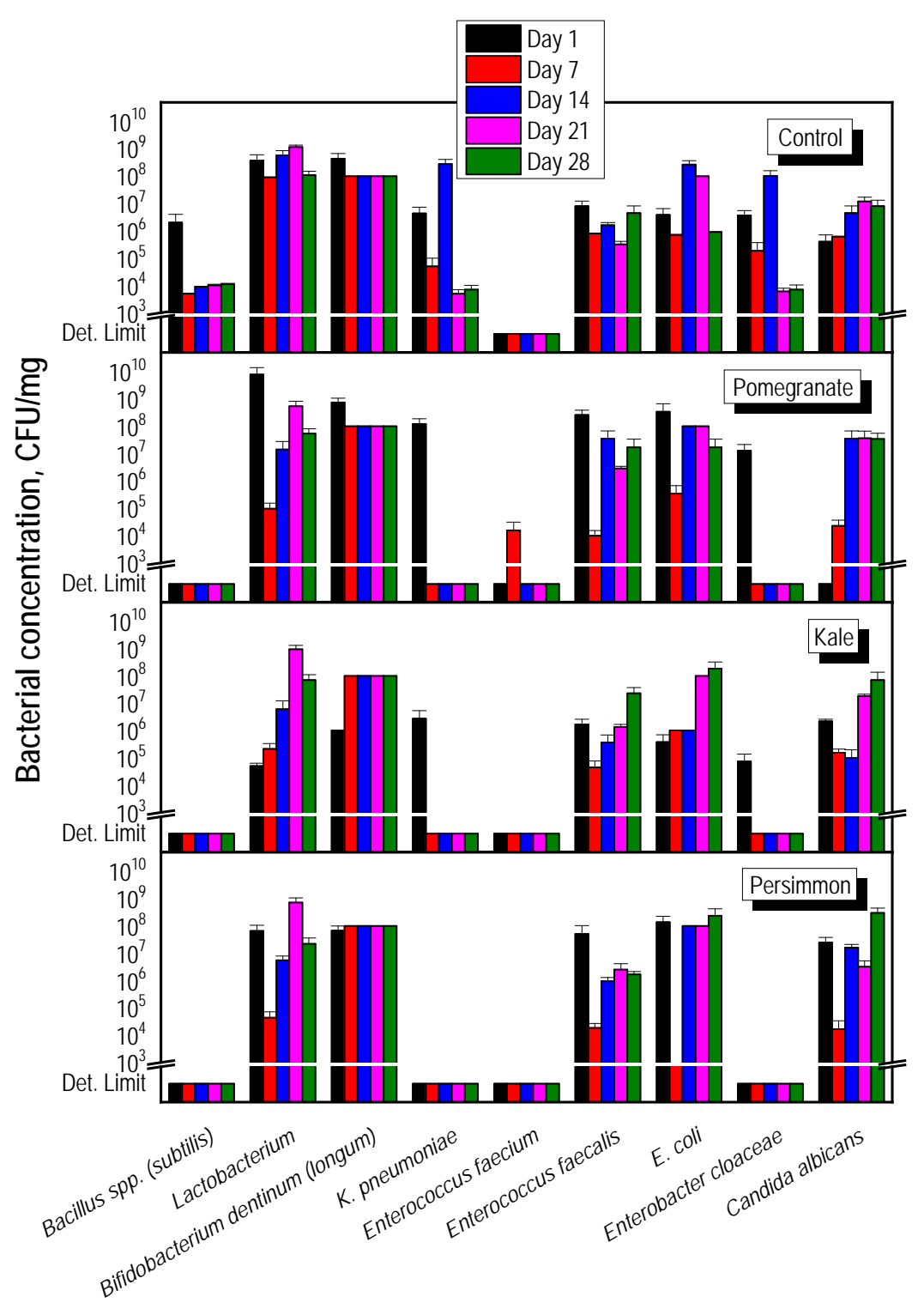

Fig. 9. Summarized data of major patterns of changes of microbiota representatives in murine gut of immunocompetent BALB/c mice: effect of kale, persimmon and pomegranate extract vs. control)- 


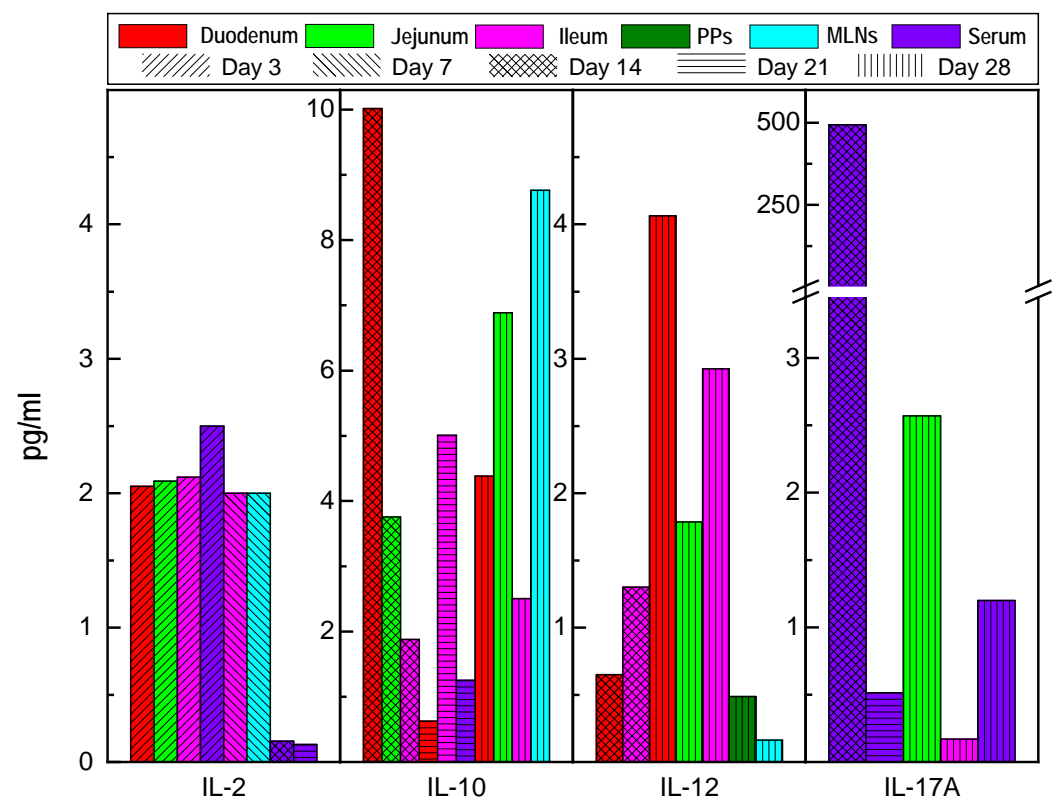

Fig. 10. Cytokines productions in a very specific manner: 4 different cytokines (from all the tested) were activated by oral administration of Kale extract

Oral administration to mice of nettle extract also leads to extremely local and strictly specific stimulation of IL-2 synthesis (in all departments of the small intestine, Peyer's plaques and mesenteric lymph nodes) within 2.37-2.0 $\mathrm{pg} / \mathrm{ml}$, as well as TNF- $\alpha$ in the lower intestine and $\mathrm{PB}(7.8 \mathrm{pg} / \mathrm{ml}$ and $7.84 \mathrm{pg} / \mathrm{ml}$, respectively).
Consumption of kale extract (Fig. 10) stimulates IL-2 synthesis from day 3 to day 7 in the small intestine and serum (2.06-2.12 pg/ml). IL-10 synthesis increased on day 14 of the experiment in the duodenum and ileum (up to $3.7 \mathrm{pg} / \mathrm{ml}$ ) and mesenteric lymph nodes $(6.0-8.7 \mathrm{pg} / \mathrm{ml})$.

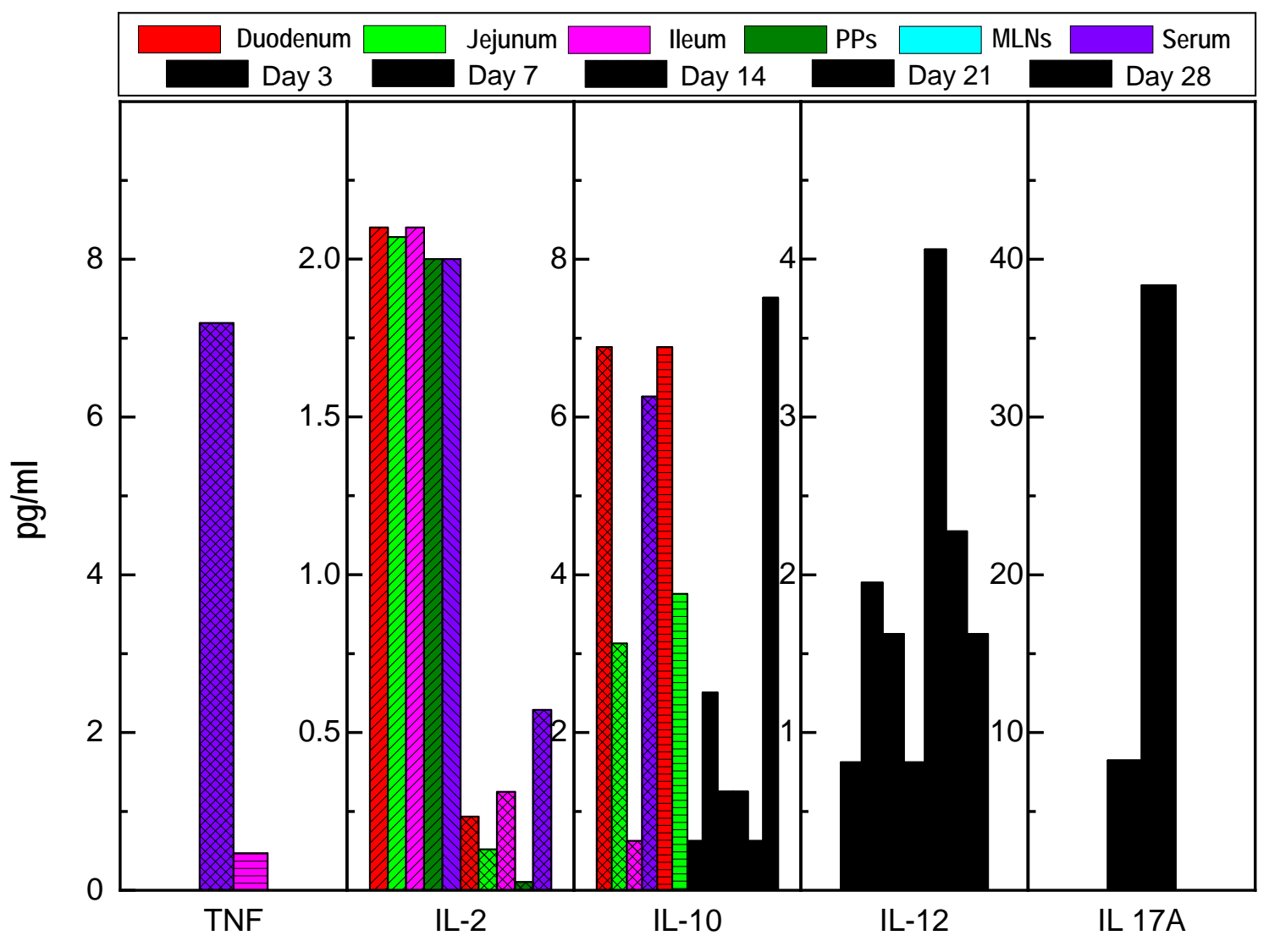

Fig. 11. Systemic and local production of cytokines as a result oral administration of persimmon extract 
Unlike IL-10, interleukin 12 is most actively produced on the $21 \mathrm{st}$ day of the experiment to $4.63 \mathrm{pg} / \mathrm{ml}$ ). It should be noted that on the 14th and 21 st day of the experiment there was an increase in the amount of IL-17A to $493.5 \mathrm{pg} / \mathrm{ml}$ in serum of laboratory animals, and on the 28th day - in the MLNs $(2.5 \mathrm{pg} / \mathrm{ml})$, which is evidence of its proinflammatory action.

We found that persimmon extract (Fig. 11) has a distinct systemic and local proinflammatory effect throughout its oral administration (ie, within 14 days). In particular, there was a sharp increase in TNF- $\alpha$ in serum of laboratory animals on the 14th day of the experiment (up to $7.1 \mathrm{pg} / \mathrm{ml}$ ), on the 7 th and 14th day, the synthesis of IL-17A in the serum of animals increased (8.22$38,34 \mathrm{pg} / \mathrm{ml}$ ), the synthesis of IL-2 (up to the level of $2.1-2.7 \mathrm{pg} / \mathrm{ml}$ ) also increases on the $3 \mathrm{rd}$ and 7 th days of oral administration of this extract. From the 14th to the 21 st day of the experiment the synthesis of IL-10 (up to $6.8-6.85 \mathrm{pg} / \mathrm{ml}$ ) is increased, with a further decrease on the 28 th day $(2.4-1.3 \mathrm{pg} / \mathrm{ml})$ and vice versa, the level of its IL-12 agonist increases significantly, starting from day 14 of the experiment in all departments of the small intestine $(4.06 \mathrm{pg} / \mathrm{ml}), \mathrm{MLN}(2.27 \mathrm{pg} / \mathrm{ml})$ and in serum (1.8 pg/ml).

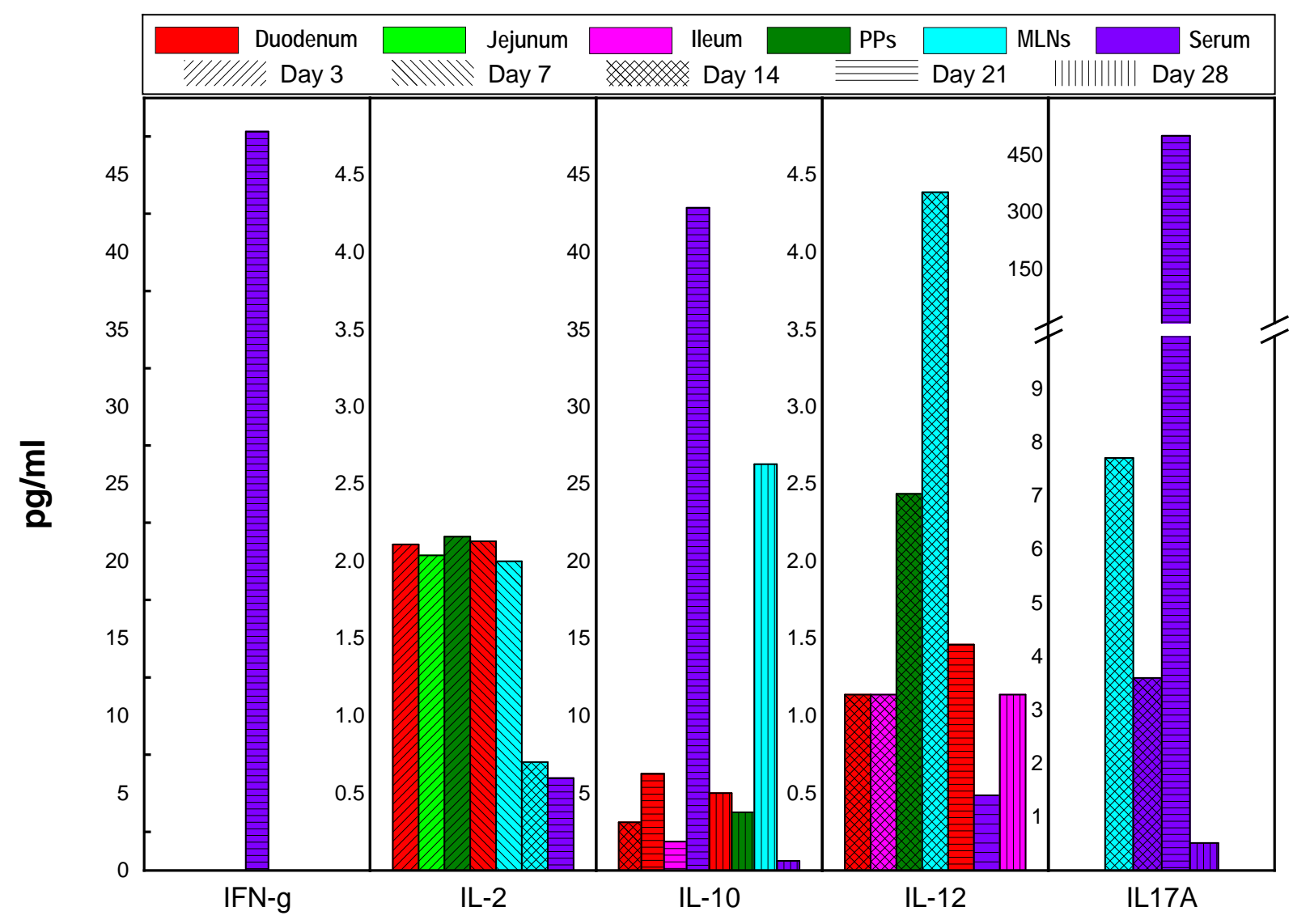

Fig. 12. Systemic and local production of cytokines as a result oral administration of pomegranate extract

Thus, the persimmon extract induces a local proinflammatory effect in the initial terms after oral administration.

Oral administration to mice of pomegranate extract (Fig. 12), similar to persimmon extract, stimulates the synthesis of IL-2 locally on the 3rd and 7th day (up to $2.11 \mathrm{pg} / \mathrm{ml}$ ) with a tendency to its sharp decrease on the $14 \mathrm{th}, 21 \mathrm{st}$ and the $28 \mathrm{th}$ day of the experiment (up to $0.7-$ $0.5 \mathrm{pg} / \mathrm{ml}$ ), and on the $21 \mathrm{st}$ day is characterized by a clear pro-inflammatory effect (IFN- $\gamma$ synthesis reaches the level of $47.81 \mathrm{pg} / \mathrm{ml}$, IL-17A-500 pg/ml). The optimal effect of this extract is observed on the 14th day of its oral administration, when the levels of proinflammatory cytokines become lowest and, conversely, the levels of anti-inflammatory cytokines (IL-12) reach a maximum in the departments of the small intestine, MDL and PB (up to $2.4-4.38 \mathrm{pg} / \mathrm{ml}$ ).

\section{Discussion}

In our study we investigated the ability of extracts of pomegranate, persimmon, nettle, dill, kale and Sideritis to modulate gut microbiome and local production of cytokines. The results of the study show no harmful influence of tested plants on murine gut microbial composition still based on our investigation we can conclude that most beneficial properties are inherent to persimmon and then pomegranate and kale. Siderites rather show no significant influence on all the studied indices while the Nettle and Dill are acting proinflammatory.

Analysing the obtained experimental data we can note that secreting of targeted cytokines initiated by oral administration of investigated plants' extracts is very specific and depends on the time point of experiment and its locations (SI, PPs, MLNs vs. serum). 
Obtained experimental data indicate the advisability of using extracts as natural strictly specific remedy of prevention and treatment of diet-associated diseases by balancing of gut microbiota and immune system. It should be noted that experimental works on the study of the specificity of action of targeted foods/plants extracts on gut microbiota and local immune response is not so much and mostly these researches are directed on studying of influence of each extracted component separately. Zhu et al. showed that supplementation with low dose of persimmon tannin induced a significant alteration in specific bacterial species by increasing some types of gut microbiota that have been inversely related to obesity (Bifidobacterium spp., Lactobacillus spp.) and reducing the relative abundance of others associated to diet-induced obesity (E. coli and Enterococcus) [14]. However, analysing the experimental data we obtained, the Persimmon extract decreased numbers of lactobacilli on 7 th day of oral administration but after the wash-out period was no statistical differences observed. Interestingly, commensal E. coli and Enterococcus was not affected by Persimmon extract. George et al. also documented that a pomegranate peel extract treated decreased levels of Lactobacillacieae in mice gut microbiota [15]. However, our obtained experimental data showed that lactobacilli were stimulated by Pomegranate on 3 day of oral administration but after wash-out period no statistical differences was observed.

In our study we did not make detection of amount of total/activated B1/B2, CD4/CD25, CD8, CD56 other immune cells subsets in spleen and different components of GALT.

Further research can be related with the using of in vivo model to reveal the specificity of action of selected foods/plants extracts on gut microbiota and immune response of mice with combined T-and B cells deficiency.

\section{Conclusions}

1. Number of Lactobacilli strains in gut content was not significantly affected by Dill and Sideritis extracts; and were stimulated by Pomegranate extract on 3, inhibited by Kale extract on 3-14 d and by Persimmon extract on $7 \mathrm{~d}$; after the wash-out period no statistical differences was observed. K. pneumoniae and E. cloacae were eliminated from mice colon by feeding of the extracts of Sideritis, dill, nettle and persimmon but not pomegranate and kale. E. faecium and E. faecalis was stimulated significantly by pomegranate extract. $B$. $b i$ fidum and $B$. longum were increased only in colon content of mice fed with extracts of Sideritis, pomegranate and kale. Interestingly, commensal E. coli was not affected by any of the tested plants' extracts significantly. All plants' extracts had promoted C. albicans persistence in mice colon; only kale extract had lowered its amount on 7-14 d but not on 21-28 $\mathrm{d}$ and after the wash-out period.

2. There are sufficient differences in produced cytokines in FC and serum of mice fed with different plants extracts. TNF-a, and IL-2 increased both systemically and locally in the different gut compartments by dill, nettle and Sideritis extracts only at mucosal sites. IL-2, but also IL-10 and IL-12, IFN-g, and IL-17 but not TNF-a were stimulated in different levels by pomegranate, persimmon and kale extracts: both systemically and locally.

\section{Conflicts of interest}

The authors declare that they have no conflicts of interest.

\section{References}

1. Woodcock, M. E., Hollands, W. J., Konic-Ristic, A., Glibetic, M., Boyko, N., Koçaoglu, B., Kroon, P. A. (2013). Bioactive-rich extracts of persimmon, but not nettle,Sideritis, dill or kale, increase eNOS activation and NO bioavailability and decrease endothelin-1 secretion by human vascular endothelial cells. Journal of the Science of Food and Agriculture, 93 (14), 3574-3580. doi: http://doi.org/10.1002/jsfa.6251

2. Konić-Ristić, A., Srdić-Rajić, T., Kardum, N., Aleksić-Veličković, V., Kroon, P. A., Hollands, W. J. et. al. (2013). Effects of bioactive-rich extracts of pomegranate, persimmon, nettle, dill, kale andSideritisand isolated bioactives on arachidonic acid induced markers of platelet activation and aggregation. Journal of the Science of Food and Agriculture, 93 (14), 3581-3587. doi: http://doi.org/10.1002/jsfa.6328

3. Pallah, O. V., Meleshko, T. V., Bati, V. V., Boyko, N. V. (2019). Extracts of edible plants as beneficial microorganisms growth stimulators. Biotechnologia Acta, 12 (3), 67-74. doi: http://doi.org/10.15407/biotech12.03.067

4. Carbonell-Capella, J. M., Barba, F. J., Esteve, M. J., Frígola, A. (2013). Quality parameters, bioactive compounds and their correlation with antioxidant capacity of commercial fruit-based baby foods. Food Science and Technology International, 20 (7), 479487. doi: http://doi.org/10.1177/1082013213492523

5. Moyer, R., Hummer, K., Wrolstad, R. E., Finn, C. (2002). Antioxidant compounds in diverse ribes and rubus germplasm. Acta Horticulturae, 585, 501-505. doi: http://doi.org/10.17660/actahortic.2002.585.80

6. Correia, R. T., Borges, K. C., Medeiros, M. F., Genovese, M. I. (2012). Bioactive compounds and phenolic-linked functionality of powdered tropical fruit residues. Food Science and Technology International, 18 (6), 539-547. doi: http://doi.org/10.1177/1082013211433077

7. Perez-Gregorio, R., Simal-Gandara, J. (2017). A Critical Review of Bioactive Food Components, and of their Functional Mechanisms, Biological Effects and Health Outcomes. Current Pharmaceutical Design, 23 (19), 2731-2741. doi: http://doi.org/10.2174/1381612823666170317122913

8. Lankelma, J. M., Nieuwdorp, M., de Vos, W. M., Wiersinga, W. J. (2015). The gut microbiota in internal medicine: implications for health and disease. The Netherlands journal of medicine, 73 (2), 61-68.

9. Oriach, C. S., Robertson, R. C., Stanton, C., Cryan, J. F., Dinan, T. G. (2016). Food for thought: The role of nutrition in the microbiota-gut-brain axis. Clinical Nutrition Experimental, 6, 25-38. doi: http://doi.org/10.1016/j.yclnex.2016.01.003

10. Chung, H., Pamp, S. J., Hill, J. A., Surana, N. K., Edelman, S. M., Troy, E. B. et. al. (2012). Gut Immune Maturation Depends on Colonization with a Host-Specific Microbiota. Cell, 149 (7), 1578-1593. doi: http://doi.org/10.1016/j.cell.2012.04.037 
11. Duan, J., Chung, H., Troy, E., Kasper, D. L. (2010). Microbial Colonization Drives Expansion of IL-1 Receptor 1Expressing and IL-17-Producing $\gamma / \delta$ T Cells. Cell Host \& Microbe, 7 (2), 140-150. doi: http://doi.org/10.1016/j.chom.2010.01.005

12. Atarashi, K., Tanoue, T., Shima, T., Imaoka, A., Kuwahara, T., Momose, Y. et. al. (2010). Induction of Colonic Regulatory T Cells by Indigenous Clostridium Species. Science, 331 (6015), 337-341. doi: http://doi.org/10.1126/science.1198469

13. Manohar, M., Baumann, D. O., Bos, N. A., Cebra, J. J. (2001). Gut Colonization of Mice withactA-Negative Mutant of Listeria monocytogenesCan Stimulate a Humoral Mucosal Immune Response. Infection and Immunity, 69 (6), 3542-3549. doi: http://doi.org/10.1128/iai.69.6.3542-3549.2001

14. Zhu, W., Lin, K., Li, K., Deng, X., Li, C. (2018). Reshaped fecal gut microbiota composition by the intake of high molecular weight persimmon tannin in normal and high-cholesterol diet-fed rats. Food \& Function, 9 (1), 541-551. doi: http://doi.org/10.1039/c7fo00995j

15. George, N. S., Cheung, L., Luthria, D. L., Santin, M., Dawson, H. D., Bhagwat, A. A., Smith, A. D. (2019). Pomegranate peel extract alters the microbiome in mice and dysbiosis caused by Citrobacter rodentium infection. Food science \& nutrition, 7 (8), 2565-2576. doi: http://doi.org/10.1002/fsn3.1106

Received date 12.02.2020

Accepted date 06.03.2020

Published date 30.04.2020

Tamara Meleshko, Senior Lecturer, Junior Researcher, Department of Clinical and Laboratory Diagnostics and Pharmacology, RDE Centre of Molecular Microbiology and Mucosal Immunology, State Higher Educational Institution «Uzhhorod National University», Narodna sq., 3, Uzhhorod, Ukraine, 88000

E-mail: meleshkotv@ukr.net

Oleksandra Pallah, Assistant, Junior Researcher, Department of Clinical and Laboratory Diagnostics and Pharmacology, RDE Centre of Molecular Microbiology and Mucosal Immunology, State Higher Educational Institution «Uzhhorod National University», Narodna sq., 3, Uzhhorod, Ukraine, 88000

E-mail: ssarvash@gmail.com

Viktor Petrov, PhD, Assistant, Department of Clinical Disciplines, State Higher Educational Institution «Uzhhorod National University», Narodna sq., 3, Uzhhorod, Ukraine, 88000

E-mail: petrovviktor.uzh@gmail.com

Nadiya Boyko, Doctor of Biological Sciences, Professor, Head of Department, Director of Center, Department of Clinical and Laboratory Diagnostics and Pharmacology, RDE Centre of Molecular Microbiology and Mucosal Immunology, State Higher Educational Institution «Uzhhorod National University», Narodna sq., 3, Uzhhorod, Ukraine, 88000

E-mail: nadiya.boyko@gmail.com 